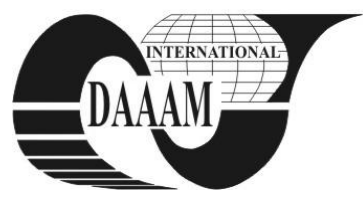

Annals of DAAAM for 2011 \& Proceedings of the 22nd International DAAAM Symposium, Volume 22, No. 1, ISSN 1726-9679 ISBN 978-3-901509-83-4, Editor B. Katalinic, Published by DAAAM International, Vienna, Austria, EU, 2011 Make Harmony between Technology and Nature, and Your Mind will Fly Free as a Bird Annals \& Proceedings of DAAAM International 2011

\title{
THE SUSTAINABLE DEVELOPMENT CONCEPT IN THE 21ST CENTURY
}

\author{
ZBORKOVA, J[itka] \& DVORAKOVA, L[ilia]
}

\begin{abstract}
This paper represents the concept of sustainable development and shows its linkage with knowledge based society.The article characterizes sustainable businesses and discusses their role and meaning in the $21^{\text {st }}$ century. Their main task is to use and multiply their knowledge potential and reflect it in their operations, management decisions and products

Key words: sustainable development, knowledge based society, business, global issues
\end{abstract}

\section{INTRODUCTION}

Today's population is nowadays known as "knowledgebased society“. Many technical gadgets and inventions are used; economic development supposedly contributes to a better life for many generations. But there is a question being discussed on the academic and political grounds: What is the impact of the human activities not only on the environment, but on the social relationships as well is it necessary to get involved with them and control them? Nowadays manufacturing and consumers' patterns are considered - even from the close future-as unsustainable.

There were several global revolutions during the evolution that were of significant impact on the organization of the human society, on social relationships and on the economic development that reflected in the area of environment and ecosystems. Human individual in its original role of a herdsman and a plunderer lived in harmony with the environment. Firstly, the human was affected by agriculture revolution which led to the first man-made interventions in the environmental area and ecosystems. The following industrial revolution led not only to growing pollution of the environment, but caused essential changes in social relationships in the whole society and in the family as well. Information revolution came after and crystallized into today's population of knowledge. However, the development has not finished yet; many scientists and experts have been discussing the evolution of our planet and predict the ecological revolution (Andrews, 2005).

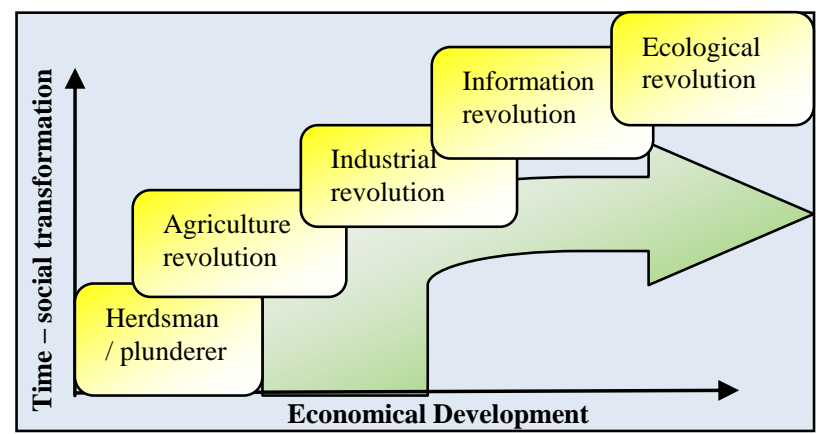

Fig. 1. Human Global Revolution

\section{SUSTAINABLE DEVELOPMENT CONCEPT}

Sustainable development concept first appeared in 70's of the last century and it's well known description defines it as the development that is in accord with the need of nowadays generation, which is not at the expense of the future generation (Gro Harlem Brundlandt). For the future development, there is the condition of an accord of 3 components: economical, environmental and social. There are many definitions, some of them are considered as misinterpreted on purpose, or they are in contradiction, at least (e.g. EU - bigger affluence within the ecosystems capacity, when maintaining natural values and biological diversity). However, no globally accepted definition has been accepted. Simply and splendidly was the idea described by the French author Antoine de Saint Exupéry: „We do not inherit the Earth from our ancestors, we borrow from our children".

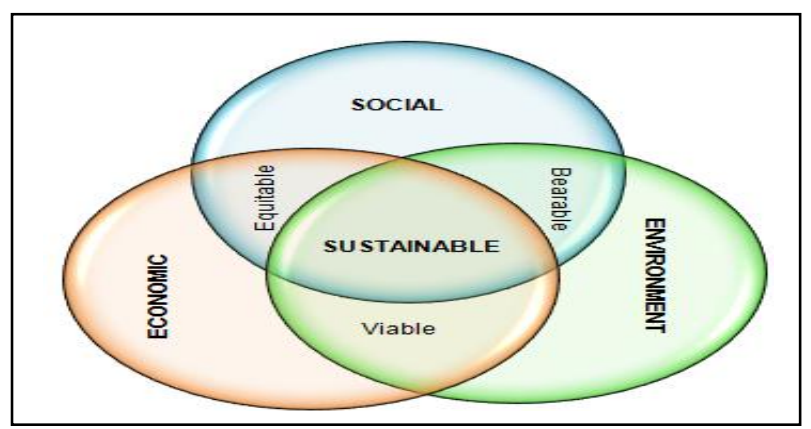

Fig. 2. Sustainable Development Concept (GRI, 2011)

\section{SUSTAINABILITY AND KNOWLEDGE}

Sustainable development concept nowadays comes out of environmental interpretation very often, however it's much wider issue. The environmental protection should be only one of many aspects, whereas the main concentration of this issue should aim on the solution of global problems of the world. The importance of knowledge in this concept is presented in the following equation, that shows the view of the capital, where different components are being introduced:

$$
\begin{aligned}
& \mathrm{K}_{\mathrm{m}}=\text { products } \quad \mathrm{K}_{\mathrm{n}}=\text { natural resources } \\
& \mathrm{K}_{\mathrm{h}}=\text { human capital } \quad \mathrm{K}_{\mathrm{c}}=\text { cultural capital } \\
& \mathrm{K}_{\mathrm{e}}=\text { ethical capital } \\
& K=\mathrm{Km}+\mathrm{Kn}+\mathrm{Kh}+\mathrm{Kc}+\mathrm{Ke}
\end{aligned}
$$

The pessimistic approach (Malthusian school, The Club of Rome) understands the capital height as determine without any possibility of an increase. The rate of substitution between natural resources and final products shows the possibility of achieving either strong or weak sustainable development.

$$
K m+K n+K h=k o n s t
$$

According to the following equation, the knowledge may help to reach the sustainable development. The level of knowledge and understanding of human society is the thing that forms the view of natural relationship - economical resources 
and the view of solving the global problems of the world (CEMC, 2005).

$$
K n<=>+K h+K c+K e=>K m
$$

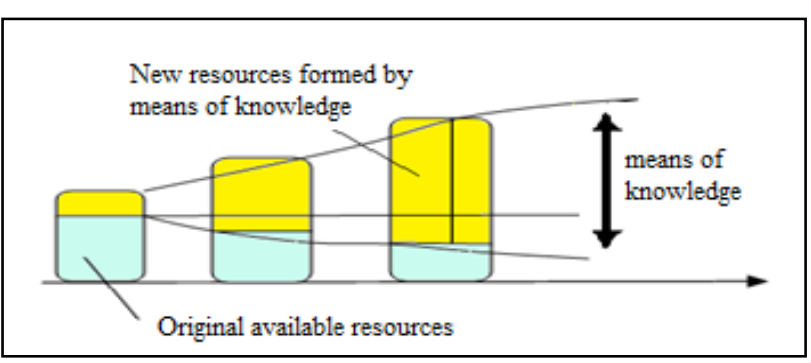

Fig. 3. Sustainable development and knowledge (CEMC, 2005)

\section{SUSTAINABILITY AT A MICRO LEVEL}

Today, we can see the effort to absorb the sustainable development concept into managing individual corporate processes. There has been a wide range of tools (both economical and voluntary), metrics and indicators developed for the measuring and evidence of the concept.

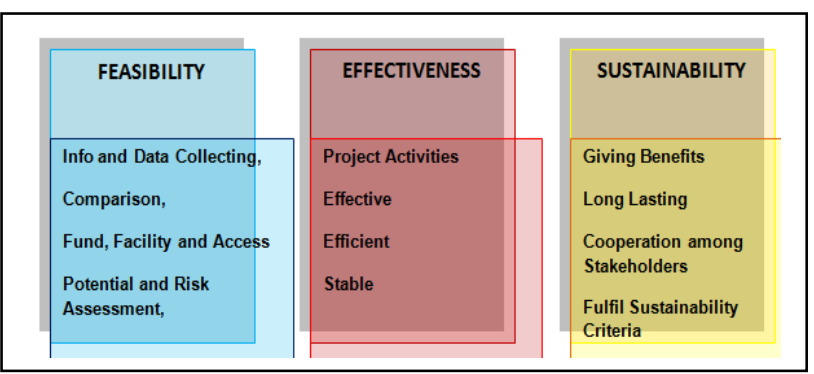

Fig. 4. Sustainable Development on micro level (Wijaya, 2009)

\section{SUSTAINABLE BUSINESSES}

According to the current opinions, the main task for the businesses is to make good and creative use of knowledge potential and multiply it in the products. This will finally result in solution of the global issues of the world.

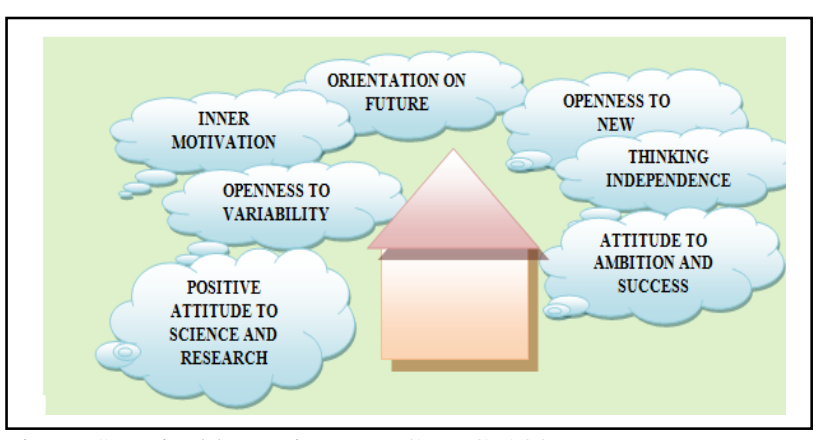

Fig. 5. Sustainable Businesses (CEMC, 2005)

\section{THE KNOWLEDGE IN SUSTAINABLE BUSINESS}

The businesses have several possibilities of how to make good use of knowledge potential and multiply it. The following belong within the basic ones:

- improvement of current processes and methods, continual upgrade,

- utilizing such as continual usage of the current knowledge in the new processes,

- innovation based on the new and revolutionary thoughts that has never been applied before.

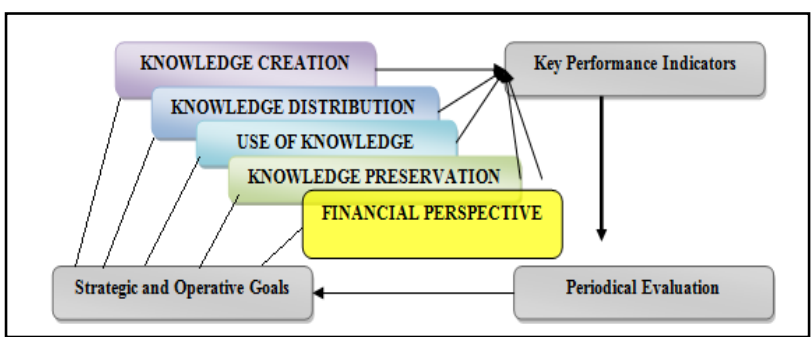

Fig. 6. Business in knowledge based society (Aurer, 2003)

\section{EVOLUTION OF ENTERPRISES - QUESTIONS}

The businesses must respect social roles that they hold towards to the stakeholders. In the course of time, understanding of the main goal for the business and the responsibility of the business against its environment has been shifted. But what is the relation between the economically successful and the sustainable business?

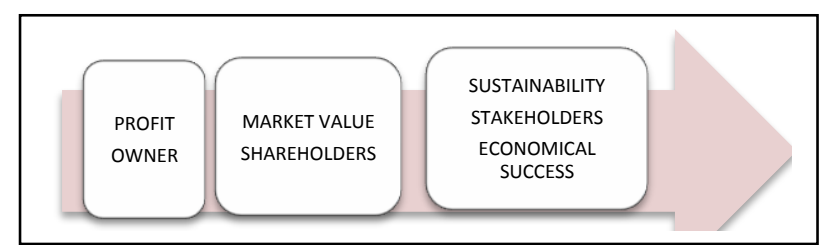

Fig. 7. Business Concepts

\section{CONCLUSION}

The knowledge-based society and the sustainable development concept represent the phenomenon of 21.century. The businesses have been adapting of to this phenomenon by progressive innovation with many voluntary tools and by publishing non-financial reports. To assess potential existence of the relation between economically successful business and the sustainable business, it is necessary to improve the quality of these reports. Even though the maximization of the profit should not be the main aspect during the management of a business, some economical prosperity to secure business functions is, of course, necessary. Our future research plans are presented by determing of the inclusion of the sustainable concept on micro level and finding the potential relation between sustainable and economic successful businesses. We will realize a questionary survey of the general public and SMEs and prepare case studies of usage and benefits sustainability accounting on micro level.

\section{REFERENCES}

Andrews, E. (2005). The Sustainability Revolution, New Society Publisher, ISBN 08-657-15-319, Gabriola Island

Aurer, T. (2003). Sustainability in Context of Knowledge Society and Demography, Available from: http://www.hrmauer.ch/downloads/Sust_e.pdf Accessed: 2011-08_04

Wijaya, W. (2009). Sustainable Development and Integrated Management Approach, Available from: http://willyyanto.wordpress.com/2010/10/18/sustainabledevelopment-and-integrated-management-approach/ Accessed on: 2011-08-03

*** (2005) http://www.cemc.cz/ - České ekologické manažerské centrum, Aplikace environmentálního účetnictví na mikroúrovni a makroúrovni v podmínkách ČR, Accessed on: 2011-07-22

*** (2011) http://www.verifysustainability.com - Global Reporting Initiative, Sustainability - the Solution Matrix Accesssed on: 2011-08-10 